\title{
The Manuscrit trouvé à Saragosse and the Thousand and one nights
}

Richard van Leeuwen

\section{(2) OpenEdition \\ 1 Journals}

Electronic version

URL: http://journals.openedition.org/edl/461

DOI: 10.4000/edl.461

ISSN: 2296-5084

Publisher

Université de Lausanne

\section{Printed version}

Date of publication: 15 December 2012

Number of pages: 133-150

ISBN: 978-2-940331-29-1

ISSN: 0014-2026

\section{Electronic reference}

Richard van Leeuwen, "The Manuscrit trouvé à Saragosse and the Thousand and one nights », Études de lettres [Online], 4 | 2012, Online since 15 December 2015, connection on 18 December 2020. URL :

http://journals.openedition.org/edl/461 ; DOl : https://doi.org/10.4000/edl.461 


\section{THE MANUSCRIT TROUVÉ À SARAGOSSE AND THE THOUSAND AND ONE NIGHTS}

Il s'agit, dans cette étude, d'analyser l'assimilation du modèle des Mille et une nuits par Jean Potocki dans le Manuscrit trouvé à Saragosse, de situer ce roman dans le courant de la réception des Nuits dans la littérature européenne et de montrer que l'intérêt de Potocki pour le grand recueil arabe, loin de résulter de quelque éphémère fantaisie, exprime et illustre l'impact profond exercé par les Nuits sur la littérature européenne, notamment sur l'évolution des formes narratives.

The eighteenth century marked a watershed in the nature of European interests in the Orient. Partly as a result of increasing commercial and diplomatic exchanges with the Ottoman Empire, both Istanbul and the Arabic provinces, the importance of learning Oriental languages and exploring Oriental cultures became widely acknowledged. Under the influence of Enlightenment thought the focus of interest in Oriental studies gradually shifted from religious polemics to secular disciplines, such as history, philology and "belles-lettres". This shift was supported by the foundation of new scholarly institutions and the construction of networks of intellectual exchange, such as the Republic of Letters. Travel to the Orient increased, not only fostering linguistic expertise, but also contributing to communication with autochthonous scholars and informants, who rapidly expanded Western knowledge of Oriental history, cultures and societies. Together these components shaped a new perception of the Orient, both as a cultural antithesis of Europe and as a source of knowledge and scholarship ${ }^{1}$.

I. See N. Dew, Orientalism in Louis XIV's France. 
The intensified interaction with the Levant, especially, resulted in the disclosure of an increasing amount of Arabic, Turkish, and Persian texts, in the form of translations and scholarly editions. In the field of literature, which interests us here, the most remarkable event was the appearance of Antoine Galland's Mille et une nuits (1704-1715), the first rendition in a European language of the Arabic collection of stories known as Alf layla wa-layla, or the Thousand and one nights. The translation became immensely popular. It was immediately re-translated into the main European languages and engendered a wave of imitations, re-workings and pastiches, especially in France, England and Germany. The text not only responded to the renewed interest in the Orient, but also to new literary tastes, influenced by the emerging traditions of fairytales, adventure novels and - authentic and imaginary - travel accounts. Apparently, it appealed to the literary needs of the Enlightenment audience, which looked for new literary forms and wider horizons ${ }^{2}$.

Within the new epistemological approaches to the Orient and its historical and intellectual contexts which emerged in the 18th century, Jean Potocki stands out not merely as a remarkable figure, but rather as the embodiment of the spirit of his age. With his inquisitive mind, his interest in the sciences, rational thought, and "belles-lettres", his inclination towards adventures and travelling, and his interference in political and diplomatic events could not but lead to a vivid interest in the Orient, and, more specifically, in Oriental storytelling and the Thousand and one nights. It is the aim of this contribution to analyze the way in which the Thousand and one nights was adopted by Potocki as a model for his major literary achievement, the novel Manuscrit trouvé à Saragosse, to situate the novel within the reception of the Nights in European literature, and to argue that Potocki's interest in the work was not merely an ephemeral whim, but rather the expression of the deep impact of the Nights on European culture and part of a structural reshaping of the literary landscape.

Before discussing the literary-historical aspects of the work, we will first summarize the parallels between the Manuscrit and the Thousand

2. For a concise overview of the circumstances and influence of Galland's translation, and bibliographical references, see U. Marzolph, R. van Leeuwen, The Arabian Nights encyclopedia; J.-P. Sermain, Les Mille et une nuits entre Orient et Occident. 
and one nights, both as it appeared in Galland's Mille et une nuits and as it can be situated in the context of the Arabic literary tradition.

\section{Manuscrit trouvé à Saragosse and the Thousand and one nights}

Throughout his life, Potocki showed a marked fascination with the Orient, directed at both scholarly and practical aims. He advocated for the foundation of a Russian Academy of Oriental Languages, after the Austrian example, and attempted to design policies for the stimulation of Asian trade. His interest is more directly expressed, however, through his own experiences in the Orient during his journeys to Spain and Morocco, Turkey and Egypt, and Mongolia and the Caucasus. These experiences are recorded in his travel accounts, which are both of scholarly and biographical interest. Potocki enjoyed immersing himself in the Oriental environment and in his Voyage en Turquie et en Egypte he relates how he roams through the alleys of Istanbul, submerging in their peaceful and tranquil atmosphere, and how he dons Oriental dress when he sets out for Egypt, as was the custom of truly adventurous travellers of the period. With keen interest he describes the customs of the Turks, Egyptians and Moroccans, focusing especially on their "morale", their psychological attitudes and behaviour, which differentiates them from Europeans.

At an early stage, Potocki showed an interest in Oriental storytelling, and his aforementioned Voyage en Turquie et en Egypte, published in 1784, when he was 23, Potocki interspersed his letters with stories and anecdotes, some quoted from, for instance, a storyteller in a coffeehouse in Constantinople, some written by himself, inspired by his readings of Oriental tales:

Je ne sais trop comment vous trouverez les apologues des Orientaux; pour moi je raffole de leur manière, et je m'y suis essayé: les lectures que j'ai faites depuis près de deux ans, m'ont rendu si riche en pensées orientales, que je n'ai eu que la peine d'en grouper quelques-unes et de leur donner des cadres. Je suis bien sûr d'avoir réussi à conserver à mes figures leur physionomie orientale, mais je ne suis pas également sûr que cette physionomie réussisse en Occident ${ }^{3}$.

3. J. Potocki, Voyage en Turquie et en Egypte, p. 26 sq. 
It seems that for Potocki these stories contain the essence of the Orient, and a medium for Europeans not only to become acquainted with the Oriental "soul", but also to learn from it and assimilate its merits:

Leur maxime est qu'il faut jouir, et non paraître jouir. De là cette philosophie si douce, qu'on ne retrouve que dans les écrits des Orientaux, qui ne s'exprime point par des paradoxes brillants, mais par des apologues d'une vérité frappante, et paraît chercher plutôt à s'épancher qu'à se répandre ${ }^{4}$.

This inclination towards storytelling explains Potocki's interest in the Thousand and one nights as a vast repository of Oriental tales of various kinds. This interest is obvious, too, throughout the account of his journey to Morocco in 1791, in which he refers to the Thousand and one nights on various occasions. When visiting the caid Potocki wraps his present in four silk handkerchiefs, as the mother of Aladdin did in the famous story in Galland's Mille et une nuits ${ }^{5}$. He remarks that the sultan refers to himself as "emir al-Moumenin", a term translated by Galland as "Commandeur des Croyants", one of the titles of the caliph ${ }^{6}$. At other places he explicitly refers to the Thousand and one nights in his descriptions of specific Moroccon phenomena, such as the towncrier $^{7}$. In Tetuan, Potocki asks a young student to procure a copy of the Thousand and one nights for him, which, according to the student, is known in Morocco as the "Three hundred fifty-four nights". The student does not succeed in finding a copy, but he returns with a work of a similar genre, called, according to Potocki, Giafar et Barmaki, in which part of the Thousand and one nights' stories can be found. Potocki reads the beginning of the text in which it is related how a sultan, chasing a white gazelle, enters an enchanted castle, covered with valuable tiles ${ }^{8}$.

It is clear from these passages that Galland's Mille et une nuits was an important source of knowledge for Potocki and a frame of reference for his observations of Moroccan life and society, heeding Galland's remark that the work contained all information about the manners and customs

\footnotetext{
4. Ibid., p. 39.

5. J. Potocki, Voyage dans l'empire de Maroc fait en l'année 1917, p. 96.

6. Ibid., p. 94.

7. Ibid., p. 111.

8. Ibid., p. 113.
} 
of the Orientals which an interested reader might need. It seems plausible to assume that the combination of his readings of the Mille et une nuits and his impressions of Morocco together provided the inspiration for his great literary project Manuscrit trouvé à Saragosse. This suggestion is strengthened by Potocki's statement that during his stay in Madrid he befriended the Moroccan ambassador in Spain, Sidi Mohammed Bin-Otman, who told him many Oriental stories which he intended to write down one time ${ }^{9}$. One of the stories of Bin-Otman is inserted in the account itself ${ }^{10}$. Apparently, during his journey through Spain and Morocco Potocki collected material, ideas and impressions from various sources, which, together with Galland's Mille et une nuits, gradually grew out to become the first drafts of the Manuscrit. Just as in the case of the Thousand and one nights, oral sources were important, reflecting the authentic act of storytelling, which is also prominent in the work itself. They were combined with other sources, which, like the Nights, were put together in a collection over a long stretch of time, being reordered and recomposed various times. Thus, the textual history of the Manuscrit to a large extent resembles the complex process in which the Thousand and one nights, at least its European branch, took shape.

These parallels between Manuscrit trouvé à Saragosse and the Thousand and one nights, with regard to the nature of the sources and the process in which the material was gathered in a single work are not without significance. They strengthen the generic connections between the two works, since they resulted in both cases in a broad diversity of material which was finally incorporated in the collections, ranging from "histoires galantes" to scientific compendiums, from fairytales to edifying allegories, from chivalrous tales to love stories. Moreover, in both cases they explain the formal structure of the work as a seemingly endless labyrinth of stories, which are loosely connected to each other, or embedded in each other, and do not seem to lead to a clear "dénouement". Although the suspense is upheld by the connection between the framing story and the embedded stories, only at the end a plot is revealed which gives coherence to the collection as a whole, and which explains its many digressions, reconciling, so to speak, the "sense of an ending" with the narrative device of postponement.

9. Ibid., p. 94 sq.

Io. Ibid., p. 109 sq. 
The origin and growth of both texts thus show that their concepts are similar, a similarity which is further elaborated in the structure of Manuscrit trouvé à Saragosse. Like the Thousand and one nights, the Manuscrit has a layered structure, which consists of a framing story and a chain of embedded stories. Of course, the device of the framestory was not unknown in European literature before the appearance of Galland's Mille et une nuits, occurring most famously in Boccaccio's Decamerone. However, in the Mille et une nuits the frame not only serves as a means to connect the embedded stories, it also creates a direct link between the two levels, in such a way that events on the level of the framed are influenced by the storytelling and the stories themselves. It is this interaction which produces not only a form of suspense, but also a form of reflexivity, exploring how storytelling affects events in "real life". In both the Manuscrit and the Nights the suspense is enhanced by the temporal character of the frame, which suggests the idea of an ultimatum.

These conceptual and formal resemblances, with their elements of self-reflexivity and meta-fictionality, link the Manuscrit first of all with the framing story of the Thousand and one nights, the story of "Shahriyâr and his brother", in which the origin and the rationale of the storytelling are explained ${ }^{11}$. In the Manuscrit, we have the "Avertissement", which relates the finding of the Manuscrit by the French officer, the possession of which saves him when his company is captured by Spanish troops. The text is subsequently dictated to the officer by the Spanish captain, while he resides in his house. The narrative does not return to this level, but in the final paragraphs of the book the hero, Alphonse van Worden, explains how he hides a copy of the book in an iron case//chest, to be found by his descendants. Whereas Potocki failed to find a manuscript of the Thousand and one nights in Morocco, a similar manuscript is claimed to be found in Zaragoza, surviving only through a coincidental turn of events. This coincidental nature of the text is significant, since it is suggested that the Manuscrit contains a life-story which is not part of official, well-known, history, but rather of a secret history, a hidden part of Spain's past.

On the second level we meet the protagonist Alphonse van Worden, who is travelling through the Sierra Morena and who spends the night

II. For a summary of the stories of the Thousand and one nights, see U. Marzolph, R. van Leeuwen, The Arabian Nights encyclopedia. 
in the inn Venta Quemada, an old Moorish stronghold where he meets the sisters Emina and Zibbedee for the first time. The sisters not only try to seduce Alphonse, but also tell him the story of the Cassar-Gomelez and the history of their family, which is interrupted by daybreak. This scene of course calls to mind the image of Shahriyâr and the two sisters Shahrazâd and Dunyazâd in the framing story of the Thousand and one nights, with its entwinement of eroticism and storytelling. In both cases it is the women who have aspired to marry the heroes, Shahriyâr and Alphonse. The parallel between Shahriyâr and Alphonse is further strengthened by their conforming to ideal types of masculinity. They are both powerful heroes, full of masculine virtues, and the paragons of noble integrity. Both, however, have in some sense become isolated in their masculinity and in the symbolic narrowness of their status and personality, and are now re-connected with various aspects of femininity, Shahriyâr through the combination of eroticism and storytelling, Alphonse through eroticism and the disclosure of a hidden part of his family's history, his being a descendant of the Moorish Gomelez family through his mother.

In the case of Shahriyâr a long trajectory of "seduction" ensues, which is meant to avert a certain death. In the case of Alphonse, the seduction is meant to have him abscond his faith and convert to Islam. This is countered, however, by the stories of the hermit and the threat of the Inquisition, subjecting Alphonse to dangers from both sides. In both cases, a kind of deadlock is created, a situation of liminality in which the position of the protagonists is, so to speak, renegotiated. Through the prolongation of the dilemma, through the postponement of the final decision, visions of life and the world are evoked in stories and discourses, with the intention to reconstruct the vision of the protagonist and make a denouement possible: The rigid, monolithic, world views of Shahriyâr and Alphonse have to be changed in order to break the deadlock, and this can only be achieved by the interference of the imagination and human ingenuity, by subjecting Shahriyâr and Alphonse to the power of the human intellect and constructing a vision of the world in which the death-threat is eliminated.

In the framing story of the Thousand and one nights the deadlock caused by Shahrazâd's postponement of her execution is part of a much more far-reaching stagnation, which is the inability of Shahriyâr to beget successors. In the story it is not explained why the first marriage of 
Shahriyâr, with the adulterous spouse, remained childless, but by installing a regime in which he marries a virgin every night who is subsequently executed in the morning, all means of procreation are aborted. The sultan will have no sons to succeed him and the dynasty will come to an end. The continuation of time will definitively be interrupted. Likewise, in Manuscrit trouvé à Saragosse, it is the dynasty of the Gomelez which seems to have reached its end. After a glorious past, the dynasty is looking for a new sheykh to secure its survival and Alphonse is chosen as a husband for Emina and Zibbedee to safeguard the continuation of the family.

In both narratives the state of stagnation, the interruption of the passage of time are related to the solid, unambiguous male identity of the protagonists, which is buttressed with forms of authority and the threat of physical violence, personified by Shahriyâr and the Inquisition. This form of monolithic identity and authority is linked to masculine qualities and juxtaposed with a non-violent strategy of seduction, persuasion and imagination, associated with feminine ingenuity. Evidently, the use of force would be no option for Shahrazâd or Emine and Zibbedee, since not only do they lack the required physical means, but the death of Shahriyâr and Alphonse would not solve the underlying problem. The only solution lies in persuasion and the procuring of affection, a transformation of the rigid mentality of the males. Thus, in both cases it is feminine imagination which penetrates into the stronghold of masculinity to achieve a gradual softening of the rigid identification with authority and violence. In both cases, the story ends with the revealing of the newborn children, which are only half-consciously begotten by Shahriyâr and Alphonse, but which ensure the continuation of the dynasty and restore the regular passage of time.

It is of course no coincidence that storytelling takes such a prominent place in the undermining of the violent form of authority. In both narratives it is suggested that the threat of violence is related to a narrow and monolithic world view, which has no vision of the complexity of reality and the possible inclusion of what is seen as different and alien. In the case of Shahriyâr it is the feminine element which is repressed; in the case of Alphonse it is the Moorish part of his identity which is not acknowledged. In both cases the narrow, inflexible world view is relativized by impregnating it with the imagination and alternative visions contained in stories, life accounts etc. In the end, the incorporation of 
the alien element and the adoption of a form of plurality acknowledging the multi-faceted nature of reality produce a new dynamism, new life and a new future. By showing how the imagination can intervene in the course of events, a new synthesis is achieved between male and female, Spanish and Moorish elements of identity based on the acceptance of the complexity of reality.

Literary patterns from Thousand and one nights

The parallels summarized above show how profoundly the stories of Shahriyâr and Shahrazâd and the Manuscrit trouvé à Sarragosse are connected, but the influence of the Thousand and one nights is not limited to the framing story only. Parallels can also be traced with a type of story which is very common in Arabic literature in general and in the Thousand and one nights more particularly: the love romance. In these stories, which resemble European medieval romances, a young hero, usually a prince or a merchant's son, sets out to find his beloved and, before reaching the object of his desire, roams through a world of wonders, enticements and threats, in which he has to find his way. Often he has to cross magical landscapes, enter enchanted spaces and oppose mysterious enemies. After he has reached his goal, he returns home and is re-incorporated into his community, usually as a successor to the throne, now comfortably married. This pattern is evident in the Manuscrit trouvé à Sarragosse as well, where Alphonse, a brave young officer, with a bright future, sets out for a journey and is suddenly caught in a rough landscape full of mysterious forces, strange events, and physical dangers. He has entered a labyrinth which shakes all his certainties and convictions, and from which he has to find a way out before he can continue his journey and assume his position at the court of the king.

Romances of this kind are usually interpreted as stories of initiation, in which an adolescent hero is subjected to a rite of passage before he can fulfil his predetermined role in society. The hero is thrown into a state of uncertainty and liminality, in which his identity has become questionable, and in which his courage, intelligence and ingenuity are tested. $\mathrm{He}$ has to confront dangers, allurements, dilemmas and obstacles, and show that he can overcome them and take the correct decisions. In the meantime his personality is re-shaped to be fit to fulfil his required tasks in 
the service of the dynasty and the community. Alphonse's predicaments seem to serve the same purpose of initiation. The state of liminality and uncertainty is symbolized by the harsh landscape of the Sierra Morena, full of brigands and unexplainable forces. His steadfastness and determination are tested in several ways; he is confronted with enemies, frightening mirages, horrors, dreams and temptations, which all unhinge his former identity and radically revise his vision of himself.

Only after he has passed his several trials successfully, that is, after he has secured the continuation of the Gomelez dynasty without relinquishing his Catholic faith, he can proceed to his destination and become what he is destined to be. As in the Arabic romances, Alphonse's initiation into sexuality and eroticism is an important element of his formation as an adult man. Significantly, the journey of initiation completed by Alphonse is mirrored by the story of the sheykh of the Gomelez about his own journey when he was an adolescent and destined to take the leadership of the family.

The idea of initiation is also the main conceptual component of another type of narrative which is common in Arabic literature, as well, that is the mirror for princes or Fürstenspiegel. As a rule, these texts consist of a framing tale in which the elements of the intrigue are explicated, and a number of inserted stories. In most narratives of this type the conduct of a young prince, often his addiction to women, threatens the survival of the dynasty and the empire. Subsequently, he is held in isolation and educated by the recitation of stories which serve as exemplary tales. Sometimes stories are told by others as well, as counter-examples to support a specific argument or case, thus providing comments on the issue at stake from different perspectives. Finally, when the education of the prince is completed, the conflict surrounding him - often of an erotic nature - is solved, and the prince is released from his liminal status. He can now assume his administrative obligations in a responsible way.

The pattern of this type of narrative clearly resembles the idea and structure of the Thousand and one nights and in fact several versions of the Nights contain various cycles of mirrors for princes, such as the stories of the "Wiles of women" and "King Jali' âd and his vizier Shimâs", suggesting that these works were considered to belong to the same genre. It may be argued, in fact, that the Thousand and one nights was inspired by examples of mirrors for princes, whose tendency towards misogyny 
has been replaced by a heroic role of the female protagonist. In Manuscrit trouvé à Saragosse it is the figure of the Sheykh of the Gomelez, who turns out to have been arranging and supervising the "education" of Alphonse, and thereby takes the place of Shahrazâd, but the elements of seduction and trial and the juxtaposition of stories, discourses, etc., link the work to the genre of the mirror for princes, which in the end results in the intellectual and moral education of the prince, but also, ultimately, of the reader.

A variant of this genre, in the Arabic tradition, is the compendium of knowledge and sciences presented as an interrogation by some authoritative figure. The most well-known example of such a compendium, containing a strong feminist motif, is the story of "Tawaddud", of which a Spanish version was made in the 13-14th centuries, entitled La donzella Teodor'. In this narrative a young slave-girl is interrogated by scholars about the principles of the major sciences, such as law, astronomy, and medicine, and in the end her knowledge proves to be superior to that of the scholars, who leave the room one by one in disgrace. This story, which contains a survey of Arabic scientific knowledge in the Middle Ages, is incorporated in some versions of the Thousand and one nights, together with a slightly more concise version inserted in the story of "Umar al-Nu' mân". The narrative device of combining a fictional setting for conveying scientific knowledge and theories is, of course, not unfamiliar to Manuscrit trouvé à Saragosse.

Finally, echoes of Arabic literary texts, and particularly of the Thousand and one nights, can be found in the embedded tales in the Manuscrit, the histories galantes and, more specifically, the history of the Gomelez family. This story, told by Emina and the sheikh himself, resembles the different types of stories of conquest, which appears especially in romances of chivalry. The typical element is the combination of the motif of conversion to Islam, piety versus idolatry and materialism, and the colonization of new territories which are subsequently brought to prosperity. 
Manuscrit trouvé à Sarragosse and the incorporation of the Thousand and one nights in the European literary field

After this brief survey of the parallels between Manuscrit trouvé à Saragosse and several Arabic literary genres and texts, we will now return to the European context of the work and its position within the European literary field. The summary of potential generic models of the Manuscrit raises the question to which sources Potocki had access, since his knowledge of Arabic was insufficient to read Arabic texts in the original language. It is possible, however, that he consulted texts with the help of interpreters, for instance when during his stay in Tetuan a student brought him a collection of stories and supposedly helped him to read the first page. Of course, the reference to this work, as quoted above, suggests that Potocki may have obtained the basic idea for the Manuscrit from this text, but it is more likely that the overall formal and thematic structure and several crucial motifs were taken from Galland's Mille et une nuits. This would be the text to which Potocki refers when he talks about the Oriental "apologues" which he has studied for several years. It should be noted, however, that Galland's version contains only a limited number of tales and that, for instance, stories such as "King Jalî‘ âd" and some typical romances were not included. Moreover, there were no other "complete" translations of the Nights at the time, nor separate translations of these and similar stories, except, for instance, older collections such as Kalîla wa-Dimna, a mirror for princes containing mainly animal fables ${ }^{12}$.

Potocki will have had access to the many imitations and reworkings of the Mille et une nuits which appeared throughout the 18th century, such as the Mille et un jours by Pétis de la Croix, the Suite des Mille et une nuits by Jacques Cazotte, the fairy tales by Christoph Wieland and the Episodes and Vathek by William Beckford. He may also have been aware of the existence of works in Spanish which were crafted after Arabic models, such as La donzella Teodor-mentioned above, Sendebar,

I2. For a discussion of the relationship between the mirrors for princes and the Thousand and one nights, see U. Marzolph, R. van Leeuwen, The Arabian Nights encyclopedia. 
Libro del caballero Zifar, and others ${ }^{13}$. In any case, his knowledge of these works may have been supplemented by informants both in Spain and Arabic countries, such as Bin-Otman, the student in Tetuan and public storytellers.

Whatever may have been the case, every effort to trace the sources of inspiration of the Manuscrit trouvé à Saragosse, Arabic or European, will place the work squarely within the literary patterns of the 18th century in general and the European reception of the Thousand and one nights more in particular. As I have argued elsewhere, the European tradition of the Thousand and one nights, which started with Galland's Mille et une nuits and was subsequently expanded with new translations, re-workings and a vast array of works inspired by its concept, structure and motifs, can be seen as a long process of incorporation, in which the work, introduced as an "exotic", "alien", element, was gradually integrated into the literary field. This process included both adaptations of the original Arabic material and an exploration of new genres and generic boundaries in European literature. The work was not merely a reservoir of Oriental images and stereotypes, it also opened up new opportunities for experiments in literature which suited the tastes of the period ${ }^{14}$.

There were several aspects of the Thousand and one nights which seem to have been especially intriguing for later European authors and which can be traced within European literature as a consistent influence. First, the formal structure of the framestory in its "interactive" form showed new perspectives of literary form, because of its self-reflexivity, its specific way of creating suspense, through plot-construction and interruption, and its juxtaposition of fantasy and reality; second, its generic diversity and, from a European perspective, generic diffuseness, lent it for all kinds of literary experiments, breaking up traditional generic boundaries inherited from the Classical period, and giving legitimacy to freer forms of narration; third, the exoticism of the work not only proved a rich source of new literary motifs, but also provided new contrasts for defining "otherness" set against an autochthonous identity; and, finally, the apparently seamless combination of realism and the intervention of supernatural forces was conducive to speculations about the relationship

13. See for the Arabic sources of these and similar works: M. J. Lacarra, Cuentistica medieval en Espana.

I4. R. van Leeuwen, "The Thousand and one nights and the formation of genres". 
between visible reality and hidden forces of various kinds, as part of a discussion involving new insights in religion and the natural sciences.

I would argue that these aspects of the Thousand and one nights, which facilitated and perhaps necessitated its incorporation into the European literary field, all converge in the Manuscrit trouvé à Saragosse and that therefore Potocki's novel should be seen as a landmark in the history of the reception of the Thousand and one nights in European culture. Whereas in previous works the influence of the formal, didactic or fantastic element prevailed, Potocki attempted to mould all these elements into a coherent whole, thus attempting to compile, it would seem, a European equivalent of the Thousand and one nights in all its richness and diversity. Moreover, the result of the effort to integrate all these elements was not a new collection of tales or a one-dimensional romance of adventure, but a work which should be seen as representing a phase in the development of the European novel, with its efforts to explore deeper layers of reality, psychological complexity and the realms of social relationships, perception and knowledge. In other words, in Manuscrit trouvé à Saragosse we can perceive the way in which the Thousand and one nights could be used for exploring the possibilities of the genre of the novel.

It seems that in Manuscrit trouvé à Saragosse not only several tendencies within European literature converged, but that the work also prefigured trends which persist until the present day. It has been argued that it is erroneous to consider the Manuscrit as belonging to the tradition of the fantastic novel, which at the end of the 18th century was represented, for instance, by Cazotte's Le diable amoureux and Beckford's Vathek. It should rather be seen as an anti-fantastic novel, since all occurrences of supernatural forces and events are in the end disclosed to have been illusions and manipulations of the sheykh of the Gomelez. Every suggestion of the existence of magical forces is wiped away, as all strange events can be rationally explained. Still, even if Manuscrit trouvé a Saragosse is not a fantastic novel, it is a novel in which the relationship between reality and potentially supernatural forces is explored, both as part of a complex reality and as an aspect of human perception and the human psyche. Even if, for Potocki's rational mind, there is no supernatural realm, reality is still more complex than it seems.

It is this explanation of the nature of reality which links Manuscrit trouvé à Saragosse with other novels which can be more unequivocally 
called "fantastic" and in which the author attempts to lay bare deeper layers of reality, both inside the human mind and in the material world. It is no coincidence that many works of this type have been inspired or influenced by the Thousand and one nights, from Cazotte, Beckford and Potocki to Von Hofmannsthal, Proust, Rushdie and Murakami. It is especially the tension between reality and the imagination, and between permeable realms of a complex, but not always visible, reality which the Thousand and one nights suggests as a theme to be explored with literary means. Perhaps it is even justified to say that Shahtazâd suggests that this exploration is no less than the essence of narration.

\section{Conclusion}

Our analysis above shows that it is justified to conclude that Manuscrit trouvé à Saragosse is a pivotal work in the transmittance of Oriental, Arabic influences to European literature, both because of its ambitious concept and through its use of Arabic literary sources. Interestingly, the incorporation of Arabic elements is not restricted to the formal structure of the work, but is also part of its theme, which deals chiefly with Islam as a repressed part of the identity of Spain. On both these levels, the model after which the work was moulded is the Thousand and one nights, which provided formal as well as conceptual matrices.

Apart from the clear formal parallels, perhaps the main element taken from the Thousand and one nights is the use of the evocation of narrative, imaginary and illusionary worlds as a strategy to undermine rigid, ideological visions of reality. The sheykh of the Gomelez conjures up an illusionary world filled with magical, enacted, happenings and performance as a means to dislodge Alphonse's one-dimensional world-view, which is based on his being brought up with the solid values of Christian Spain. It is especially the suggestion of magic which is conducive to this deconstruction, since it is contradictory to both Christian and rationalistic views of reality. Moreover, in the European mind, magic was specifically associated with the Orient and it thus contributes to the sense of estrangement which Alphonse experiences in the Sierra Morena. In the end, the magical events turn out to be illusions concocted by the sheikh, but the narrative shows that the evocation of "unreality" can help to 
reconstruct visions of reality and thereby influence the course of events, as often occurs in the Thousand and one nights.

Potocki's aim with this deconstruction seems to be the re-acknowledgement of the Moorish component of the Spanish past, which has remained hidden and slumbering without being recognized. The Gomelez have, so to speak, been isolated from the mainstream of history and condemned literally to an underground existence. It is conspicuous that they are described as Shiites, which implies that also in the Muslim periods of Spanish history they were a minority community, not incorporated into the main institutions of authority and always planning to penetrate into the centres of power. Moreover, the Shiites are allowed to conceal their true religious identity through dissimulation, or taqiyya, and have an important messianic component in their doctrines. These aspects evidently enhanced Potocki's means to create suspense and to play with the idea of a hidden community scheming to conquer the world. And the fact that they are hidden is part of their subversive strategies.

In the end all these disquieting elements are relegated to their proper places. The magic turns out to be simple manipulations and the rationalist view of reality is restored. The stronghold of the Gomelez in the Sierra Morena is dismantled and their dynasty continues to prosper, not in Spain, but in North Africa. This is only achieved, however, after Alphonse has acknowledged his appurtenance to the Gomelez family and has accepted it as part of his identity. Only in this way can the Gomelez family emerge out of their isolation and be taken up in the course of history. Only by acknowledging the Islamic component can Spanish history be complete, although it is not necessary to give up the Christian component: In the end each element has its proper place. It is this vision of plurality which seems to be Potocki's message, and there is no better narrative model to express it than the Thousand and one nights.

\author{
Richard VAN LEEUWEN \\ Université d'Amsterdam
}




\section{BIBLIOGRAPHY}

Texts

MTS-1810 = Ротоскі, Jean, Manuscrit trouvé à Saragosse (version de 1810), éd. par François Rosset, Dominique Triaire, Paris, Flammarion, 2008 (GF 1343).

-, Voyage en Turquie et en Egypte, in Euvres, t. 1, éd. par François Rosset, Dominique Triaire, Louvain, Peeters, 2004.

-, Voyage dans l'empire du Maroc fait en l'année 1791, in Euvres, t. 1, éd. par François Rosset, Dominique Triaire, Louvain, Peeters, 2004.

\section{Studies}

Dew, Nicholas, Orientalism in Louis XIV's France, Oxford, Oxford University Press, 2009.

Lacarra, María Jesús, Cuentistica medieval en Espana: los origenes, Zaragoza, Departamento de Literature Espanola, Universidad de Zaragoza, s.d.

LeEuwen, Richard van, "The Thousand and one nights and the formation of genres: the case of Jacques Cazotte", in Crossings and passages in genre and culture, ed. by Christian Szyska, Friederike Pannewick, Wiesbaden, Reichert Verlag, 2003, p. 53-63.

Marzolph, Ulrich, Leeuwen, Richard van, The Arabian Nights encyclopedia, 2 vols, Santa Barbara, ABC-Clio, 2004.

Sermain, Jean-Paul, Les Mille et une nuits, entre Orient et Occident, Paris, Desjonquères, 2009. 
